\title{
REMOTE EXPERIMENTS - THE LATEST TECHNOLOGIES IN PHYSICS CLASSES
}

\section{Miroslava OŽVOLDOVÁ-Michaela ŽOVÍNOVÁ}

\begin{abstract}
Within the paper we present real remote experiment "Free fall of a body in a glass tube". The experiment is based on the movement of a permanent magnet in a glass tube with induction pick up coils for position measurement. The paper also shows the possibilities of implementation of this experiment to direct educational process as a part of new strategy of education - Integrated eLearning $(I N T e-L)$. For this purpose we created the compact file of INTe-L components - real remote experiment, virtual experiment and e-textbook - combined with additional materials for the complex covering of the class devoted to the theme of free fall with the use of interactive blackboard.
\end{abstract}

Key words: Integrated e-Learning, remote experiment, virtual experiment, e-textbook, INTe-L packet.

\section{VZDIALENÉ EXPERIMENTY - NAJNOVŠIE TECHNOLÓGIE VO VÝUČBE FYZIKY}

Abstrakt: Príspevok prezentuje reálny vzdialený experiment Volný pád v sklenenej trubici, ktorý je založený na pohybe permanentného magnetu v trubici s navinutými medenými cievkami slúžiacimi na určovanie jeho okamžitej polohy. $V$ príspevku taktiež predstavíme možnost' implementácie prezentovaného experimentu do priameho vyučovacieho procesu s podporou Integrovaného eLearningu (INTe-L) - novej stratégie výučby. Za týmto úćelom sme vytvorili kompaktný produkt súbor pozostávajúci zo základných komponentov stratégie INTe-L: reálny vzdialený experiment, virtuálny experiment a študijný e-materiál, ako id’alši doplnkový materiál. Vytvorená pomôcka komplexne pokrýva potreby výučby fyziky v rámci témy ,Volný pád“s využitím interaktívnej tabule.

Keywords: Integrovaný e-Learning, vzdialený experiment, virtuálny experiment, študijný e-materiál, INTe-L balik.

\section{Introduction}

Rapid Development of the Information and Communication Technologies (ICT) has broadened the possibilities of their use in our everyday life. The field of education is not the exception. E-learning has become very popular and common at our schools (not only at universities but also at secondary and sometimes even at primary schools). But in recent past it was impossible to implement e-learning to the education of natural sciences because of the experiment that is irrecoverable part of them. Today we can say this period is over and due to virtual and remote laboratories we are able to use e-learning within the subjects of Physics, Biology and Chemistry.

We are completely conscious of the exclusive position of the experiment in natural sciences. In this respect we made a research among physics and chemistry teachers who teach at Slovak grammar schools. We were interested in their attitude toward experiments in educational process; we wanted to know kinds of experiments they use and of course we wanted to know what they know about the technology of remote laboratories and experiments. We have used the method of questionnaire that consisted of 7 questions - e.g. Do you use experiments within your classes? Which kind of experiments do you use? Have you ever heard about remote experiments? What is your attitude towards the use of remote experiments in the educational process?. The answers show demonstration experiments are still dominant in the educational process. They are sometimes supplemented by virtual experiments, applets and simulations. The field of remote experiments is still unknown for Slovak teachers. But what is encouraging is the fact that these teachers are really very interested

in remote experiments (and not only young teachers but also teachers with long pedagogical practices). So important is to introduce remote experiments and maybe also to show and explain the possibilities of their implementation to the direct educational process. According to these demand we prepare publication devoted to the review of remote experiments and their detailed introduction. 
The aim of the paper is to show the possibilities of the implementation of new ICT into the educational process. We focus on the exploratory function of physics connected with project based and web-based education, both utilized in Integrated e-Learning (INTe-L), a new strategy of education that brings new ways of presentation of Physics to schools.

We want to introduce INTe-L, the new strategy of education and to present a real remote experiment demonstrating a free fall of a body in a glass tube, which is a basic constituent of the ready-used packet "Free fall". We also want to show the possibilities of education based on this strategy by using the innovative multimedia educational tools.

\section{Integrated e-Learning}

The INTe-L strategy was formulated during the effort of ICT implementation into the educational process and it was integrated into the direct education at the University of Trnava, as a part of the training of future Physics teachers [2]. The strategy is based on the methods of scientific work that were declared by Carl Wieman, a laureate of Nobel Prize in Physics [1]. The main features of these methods are observations, search for proper information, its processing and storing, organization and planning of work, data and results presentation, etc.

"INTe- $L$ is the interactive strategy of teaching and learning based on the observation of the real world phenomena by the real e-experiment, esimulations based on the principal features of the physic laws and e-teaching tools such as interactive e-textbooks, manuals and instructions providing information and theoretical background for the understanding and quantification of observed phenomena [3]."

Generally, INTe-L is a higher generation of classic e-Learning supplemented by experiment that is an integral part of the education of natural sciences. It is based on three components that will be introduced in detail.

Real remote experiments

Remote experiment is a real experiment with real laboratory instruments and equipment that can be controlled by a user from his/her computer through the Internet. From every place around the world, we can run this experiment, change the values of adjustable quantities and, after the measurement, we can import the experimental data into our computer. Some of the real elaboratories, e.g. www.ises.info, http://kf.truni.sk/ remotelab in Czech and Slovak Republics, http://rcl.physik.uni-kl.de/in Germany, are accessible to all the users. This accessibility enables us to implement them into the educational process.

Simulations as virtual experiments

The second component of INTe-L is a virtual experiment or applet. Most often, it is a kind of Java application that simulates different phenomena of real world. It runs within an html page opened by user. Typical example of page with well known and popular simulations is the page of Colorado University at Boulder on http://phet.colorado.edu.

The presence of virtual experiments in the educational process enables the teacher to demonstrate many real phenomena that otherwise could not be presented in classes (e.g. a free fall on Mars etc.).

E-textbooks, manuals and instructions

E-textbook and instructional manuals serve as a supplement to classical textbooks. Besides the theory, these materials are often full of animations that make the work with the book more effective and attractive. They often contain testing programs that generate series of questions. As a result, the student can verify his/her knowledge.

Owing to the general absence of real remote experiments in Mechanics, we have not been able to apply INTe-L to this thematic unit (the application was possible when the remote experiment was replaced by a classic hands-on experiment). We therefore designed and constructed the experiment called "Free fall of a body in a glass tube".

\section{Free fall of a body in a glass tube - A Real remote experiment}

Teaching Mechanics is usually a starting point of any basic physics university course, where the support of experiments is decisive and the remote experiments are generally absent [4] due to the difficulties in technical implementation of any mechanical experiments: it requires the construction of PC controlled actuators able to pick up the motion lasting only a couple of seconds or even a split of a second. The second problem is the experimental equipment which has to be constructed in the way enabling to move it to its starting position remotely. The latter step is often very complicated.

Computer assisted experiment

The basis of all our solutions for hands-on computer (PC) assisted experiment "Free fall" is the Internet School Experimental system (ISES) 
enabling both hardware solutions (tube with coils ISES, signal V-meter module ISES) and software support (signal recording and data smoothing, processing - recording of chosen typical data, fitting, etc.) [5]. The experiment is based on the movement of permanent magnet in a glass tube with induction pick up coils for position measurement.

The experimental equipment consists of a glass tube $1 \mathrm{~m}$ long that has a constant diameter 1 $\mathrm{cm}$. On its surface, there are 10 copper coils (Fig 1). They are joined in series and connected with the V-meter module that measures electromotive voltage induced in coins.

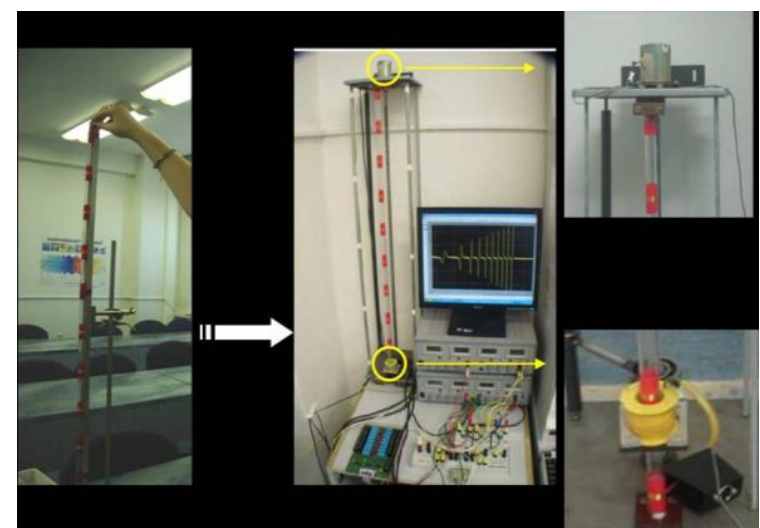

Fig 1: Transformation of the hand-on experiment to the remote one with two details: the magnetic vessel (down) and the step motor (up).

During the experiment, we explored a free fall of a magnet that falls in the tube that is opened on its lower end. The equipment is connected with the PC with ISES software that enables us to save and evaluate the experimental data. Detail description you can find elsewhere [6].

Graphical output can have the form of time dependence of the instantaneous position or electromotive voltage. We also made a series of measurements in viscous media when the tube was filled with liquid [5]. We were able to explore the consolidation of the velocity while the magnet was moving forward with zero acceleration.

\section{Transformation of PC experiment to a remote} one

We used ISES WEB Control kit to simply transform the hands-on experiment to a remote one. The prerequisite for remote control of the experiment was to resolve the repetitive lift of the magnet to its starting position. We had to replace the experimentalist who did it manually. For this purpose, we constructed a magnetic vessel surrounding the tube. It is lifted by the step motor driving the screw (Fig. 2). When the vessel is switched on, the magnetic field is induced in its centre. This field is strong enough to capture the magnet. The vessel with the magnet is then lifted by the screw driven by the step motor to the starting position. Here, the voltage in the vessel is switched off, the field in it disappears and the magnet falls down.

The second step was to project visual appearance of the web page and to arrange the flow chart that is the base for the program controlling the course of the experiment. Thereafter we needed to establish the serverclient connection; for this purpose, we used ISES WEB Control software. The technology of developing web pages of remote experiments on the base of the system ISES consists of inserting the prepared building blocks into html program, formed by the compiled Java applets for typical controls and graphs and setting their parameters [5].

The next logic step was the transformation of the hands-on experiment to the remote one on www address http://remotelab4.truni.sk (Fig 2) and its implementation into the e-laboratory in the Department of Physics, University of Trnava - http://kf.truni.sk/remotelab.

Of course, we keep working to upgrade the experiment in order to provide the best possible and accurate data, to eliminate the resistance of the air in the tube in order to realize the motion in the vacuum. Besides, the air the tube is supposed to be filled with various liquids to study damped motion and corresponding viscosities in a dissipative medium, etc.

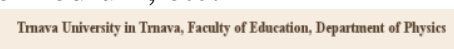

Free fall

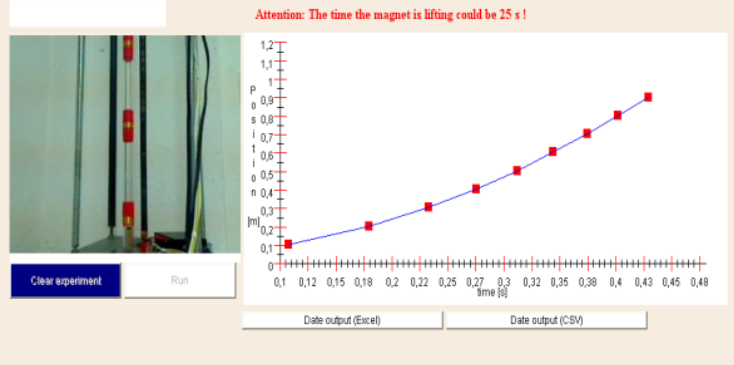

Fig 2: $W W W$ page of the remote experiment http://remotelab4.truni.sk.

The web page of the experiment (Fig 2) displays the image of the experiment from the web camera (that picks up the lower part of the tube with the magnetic vessel in its sleep mode), buttons LIFTING and RUN (that control the lift of the magnet and the start of the fall), a graph 
and two buttons below it to export the experimental data in the form of MS Excel or as CSV. If the LIFTING button is green, it is active; the user can control the experiment and start lifting the magnet. If the button is not active, the experiment is controlled by another experimenter who can work with it for five minutes. After this time, the control of the experiment is switched off automatically on another experimenter (i.e. in the case two experimenters visit this page, the other one will wait for five minutes maximum). The reservation system will be prepared soon. When the LIFTING button is pushed, the vessel with the magnet starts moving upward; the time of the lift is approximately 25 seconds. When the RUN button becomes active, the user can drop the magnet. The experimental data are immediately shown in the graph and they are ready to be exported in the form of numerical values. Meantime, the CLEAR EXPERIMENT button signals that the vessel is coming back to its primary position.

When the CLEAR EXPERIMENT button turns to the LIFTING button again, the user can repeat the measurement. Measurement of the "Free fall of a body in a glass tube" experiment works on the principle of gravity and of Faraday's law of induction for detection of instantaneous position.

\section{Evaluation of experimental data}

The experimental data from real remote experiment that are imported into a client computer are evaluated by using graphical methods. One of the possibilities is to calculate the acceleration of gravity (the magnitude of which is influenced by the effect of dissipative forces in the tube).

\section{Free fall INTe-L packet}

The implementation of INTe-L strategy into the educational process means the teacher has to choose a real remote experiment, appropriate virtual experiments, e-textbook or e-study material from given area and to combine them in an appropriate way so that the lesson forms a compact and attractive unit. As an example, we designed a complete file of INTe-L components (with supplementary materials) ready to be used in direct educational process in the secondary grammar school Unit "Mechanics - free fall".

The packet was designed using an interactive board (SMART Board) software Notebook. One of the advantages of this software is the presence of Flash applications (e.g. multiple choice, pairs or anagrams) that can be edited according to users' needs. We used them to prepare the tests and games for students. This software enables us to insert texts, pictures, animations etc. to create interactive teaching tool [7]. In the following part, we will introduce the "Free fall" INTe-L packet that covers the needs of the whole educational process starting from the motivational phase up to the control one. The packet consists of few pages interconnected by means of hypertext. It works similarly to classic web pages; from the introductory page, we can reach individual parts of the packet. MENU (Fig 3) consists of motivation, INTe-L, glossary, tests and games.

During the preparation of the packet, we took into consideration several factors that consequently influenced its content and format:

- The way of presentation and acquisition of knowledge preferred within INTe-L strategy, i.e. from active observation and experimentation to acquisition of new information [3];

- Control phase of educational process or distance learning where it is necessary to control not only learned theory but also the ability to read graphs and to apply wellknown equations to solve problems;

- Didactic principle of visualization [8] - the material contains pictures, photos, videos and, in general, it is designed to motivate.

In this part, we would like to introduce five individual parts of the packet. We tried to implement a few unconventional features that are not a typical part of physics lessons, e.g. the abovementioned real remote experiment or didactic games that enable to practice the acquired knowledge in an entertaining and competitive form.

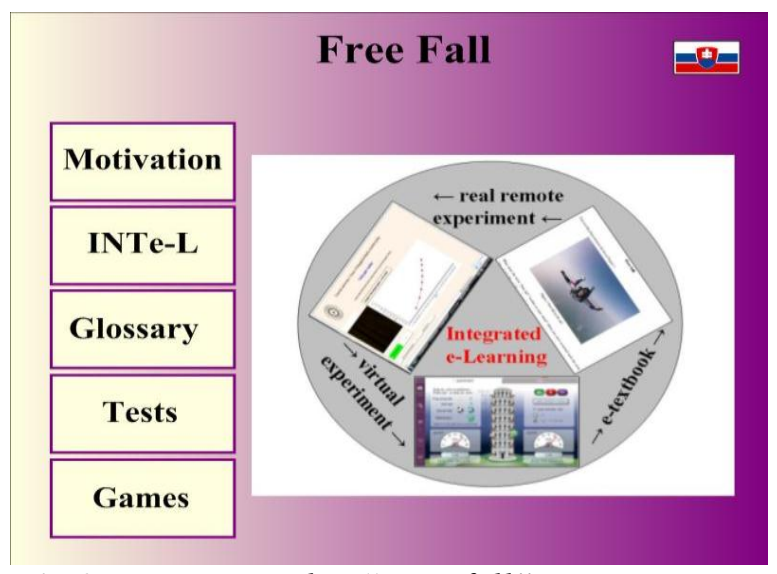

Fig 3: INTe-L packet "Free fall" - page MENU. 


\section{Content of the packet - Motivation}

We decided to motivate our students by means of simple and famous problematic questions and students' predictions for the correct solving problem: "The feather and hammer are thrown vertically with a zero initial speed. How will the feather and hammer be moving when dropped from the same height on the Earth and on the Moon?"

After a short discussion with students, we answer this question by using a video (a part of the packet) showing an astronaut on the Moon, who proves that, in vacuum, both these objects reach the ground at the same time. Free fall on the Earth can be experimentally examined.

\section{Content of the INTe-L packet}

The main part of the packet contains the access to basic INTe-L components: real remote experiment, virtual experiment and e-study material.

- The entry "Real remote experiment" is the reference to the "Free fall" experiment; here, user can find not only the experiment but also physical background, assignment for the secondary grammar school, a guide, photo gallery and a real video as an example of the running experiment.

- Within the part "Virtual experiment" (Fig 4), we prepared a virtual laboratory containing three simulations on the Internet and one animation. This animation was developed by Mathcad software. The aim is that the student experiments with different gravitational fields and realizes the consequence when "we travel from one planet to another" (how this "travelling" influences the motion). To make the work with virtual laboratory effective, we included a "Student Worksheet" containing the questions and tasks related to the experiments.

- E-study material is a pdf document developed for the needs of this packet. It contains motivational questions, basic theory, example of the exploration of free fall in laboratory conditions and an exemplary problem with numerical and graphical solutions. In theory, we emphasize the fact that free fall is an example of motion with constant acceleration. Students should realize that the equations for both these motions are identical in their base so it is not necessary to learn them as two completely different equations (as happens in many cases).

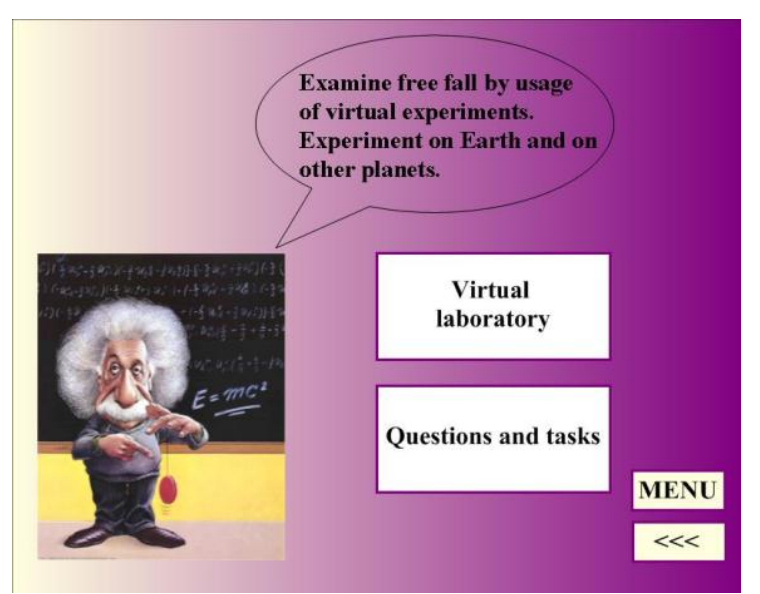

Fig 4: INTe-L packet "Free fall" - page Virtual experiment.

\section{Content of the Glossary packet}

This part contains basic terminology related to the "free fall" topic. It embodies the terms that were mentioned within the classes about free fall, motions or gravitation.

\section{Content of the Tests packet}

This part (together with the item of Games) is devoted to controlling the knowledge of students. It is required in distance study where there is no other chance of feedback for students. The section contains an entry test, final test and problems. The entry test verifies the knowledge acquired during the previous classes. The final test is devoted to free fall so that the student can test his/her level of acquired knowledge. Both these tests are multiple choice tests, only one of four possibilities is the right choice. Tests together with interactive games were developed by using Flash applications that can be found in Gallery of software Notebook. One of their advantages is easy editing even during the running lesson so that the teacher is able to modify them according to the needs of his/her students. It also means that they can be used by teachers with low computer literacy. Within this part of the packet, students can use an interactive calculator for basic numerical operations. Content of the Games packet

This part (Fig 5) contains the activities that practice new information in an entertaining way. They are focused on the knowledge connected with free fall, uniform motion and motion with constant acceleration. In the packet there are two interactive and two noninteractive games: 


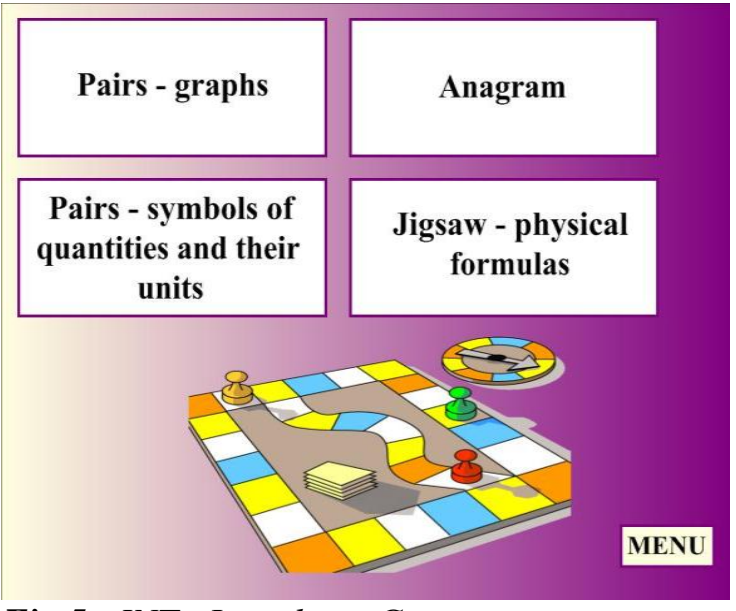

Fig 5: INTe-L packet-Games.

- Pairs - students have to find physical quantity and a corresponding unit.

- Anagram - according to clue that defines a certain term, students have to compose it. During this composition, time is running out.

- Graphs - a non-interactive game; it contains a table with six windows - in each, there is a type of graph written down and the student has to insert the appropriate graph into them.

- Jigsaw - Physical equations - noninteractive; from the given quantities and mathematical operations, design physical equations for free fall and uniform motion.

\section{Conclusion}

In the presented paper, we introduced a new strategy of education - Integrated e-Learning via INTe-L packet "Free fall". The fundamental part of it is an experiment, both real remote and virtual, that is an integrated part of the education of natural sciences.

Due to the absence of open real remote experiments in Mechanics, we designed and built the remote experiment "Free fall of a body in a tube" available on http://remotelab4.truni.sk. The design and its construction were the assumption for INTe-L application to the topic of "free fall".

In the following step, we designed a compact INTe-L packet combining basic components of INTe-L with additional materials useful in the educational process. During its preparation, we had in mind its purpose - to be used not only by the secondary grammar school students but also by those in distant study.

The packet offers a complex product that enables teachers to implement INTe-L into direct educational process and we hope that:
- It is a good example of inquiry constructivist teaching and learning for prospective and also in-service teachers;

- It actively involves every learner in the construction of knowledge;

- It demonstrates the utilization of the latest ICT into educational process with better visualization, experimentation via Internet.

This material is the first product that contains all the three INTe-L components with supplementary activities. In near future, it will be available on the Internet. We would be happy to find the positive response from the teachers and students working with the packet. The valuable research data of physics learning with the aid of performed educational tool "INTe-L packet Free fall" is prepared and will soon be piloted and analyzed. The pilot research with a small group of non-major students in secondary school is being prepared and the gained results will be discussed later.

In terms of instructional design for the prepared Free fall packet, we hope that it will help us to

- promote the topic of "free fall" (and after developing more packets, to promote Physics as a whole);

- introduce INTe-L strategy to wider community;

- present the first Slovak e-laboratory available free of charge on the Internet for all interested parties.

\section{References}

[1] WIEMAN, C., PERKINS, K. Transforming physics education. Physics Today. 2005, Vol. 58, pp. 36-41.

[2] OŽVOLDOVÁ, M., SCHAUER, F., LUSTIG, F., DEKAR, M. Real remote mass spring laboratory experiments across Internetinherent part of Integrated e-Learning of oscillations. Proceedings of Conference ICL 2007, Villach, Austria, 2007.

[3] SCHAUER, F., OŽVOLDOVÁ, M., LUSTIG, F. Integrated e-Learning - new strategy of cognition of real world in teaching physics," Innovations 2009. World Innovations in Engineering Education and Research iNEER, Special volume 2009, ISBN 978-0-9741252-9-9. [4] OŽVOLDOVÁ, M. Integrated e-Learning for freshmen of distance engineering education. Proceeding of 2009 International Symposium on Total Engineering Education. Shanghai, China, 2009, pp. $217-232$. 
[5] OŽVOLDOVÁ, M., SCHAUER, F., BEŇO, M., ŽOVÍNOVÁ, M. Real interactive free fall experiment with data collection and transfer across Internet. Proceeding of International Conference ,Multimedia in Physics Teaching and Learning Conference, Udine, Italy, 2009.

[6] SCHAUER, F., LUSTIG, F., DVOŘÁK, J., OŽVOLDOVÁ, M. Easy to build remote laboratory with data transfer using ISES Internet School Experimental System. Eur. J. Phys. No. 29, 2008, pp. 753-765.

[7] DOSTÁL, J. Interactive whiteboard in instruction. Journal of Technology and Information Education. 2009, Olomouc - EU, Univerzita Palackého, Vol. 1, No. 3, s. 11 - 16.
ISSN 1803-537X (print). ISSN 1803-6805 (online).

[8] TUREK, I. Didaktika. Bratislava: Iura Edition, 2009. 595 s., ISBN 978-80-8078-198-9.

doc. RNDr. Miroslava Ožvoldová, CSc.

Mgr. Michaela Žovínová

Katedra fyziky

Pedagogická fakulta Trnavskej univerzity

Priemyselná 4

91843 Trnava, SR

Tel: +421905847 201

E-mail: mozvoldo@truni.sk, zovinova.michaela@centrum.sk 